\title{
Leaf Anatomy of Three Varians of Arundina graminifolia (D. Don.) Hochr
}

\author{
Diah Sulistiarini $\left.{ }^{\star}\right)$ dan Eka Fatmawati Tihurua \\ Botany Division, Research Center for Biology - Indonesian Institute of Sciences \\ Jl. Raya Jakarta - Bogor KM 46, Cibinong \\ Diterima 10-03-2008 Disetujui 05-01-2009
}

\begin{abstract}
Three variations of Arundina graminifolia flowers have been recognized, (1) group of big flower with reddish violet lip and purplelish white sepals and petals (2) group of small flower with white lip and white sepals and petals (3) similar to second variation but with purple color on the lip apex. In order to clarify the taxonomy status of those three variations, a leaf anatomical study had been carried out. Results of this study showed that there were some differences among them in trichome shape and number mesophyll layers. Big flower group of Arundina has trichome club shape and thick mucous in the apex with mesophyll layer 9-11; for small flower group has white lip, trichome club shape, thick mucous and granulate in the apex, but only 2 mesophyl layers; whereas for other small flower group with purple lip has trichome cup shape and 10-13 layers of mesophyll. Based on the differences in flower size and their color variation, and combined with leaf anatomical study, we suggested the three variations of $\boldsymbol{A}$. graminifolia should be in separated groups.
\end{abstract}

Keywords: leaf anatomy, orchid, Arundina graminifolia

\section{INTRODUCTION}

Arundina graminifolia is one of terrestrial orchid that usually grows well on rocky areas. It grows in clump, with erect woody stem, which covered by overlapping leaf sheath, leaves narrow and grass-like. Inflorescence terminal, and some time branched, with flowers were not blooming in simultaneous, only 1-2 which bloom concurrently.

Arundina is a monotypic orchid with one species only i.e. Arundina graminifolia (D.Don.) Hochr. The synonyms of this species are Arundina speciosa Bl., A. bambusifolia Lindl., $A$. densa Lindl and $A$. revolute Hook.f. Based on the size and color of flowers there are some variation of Arundina graminifolia (D.Don.) Hochr. At least three groups of Arundina graminifolia (D.Don.) Hochr are recognized. The first group consists of individuals, which characterized by big flower with reddish purple lip and pale violet calyx and corolla. The second group consists of individuals, which is relative smaller flowers with pure white calyx and corolla, and white lip. The last group is similar to the second group, but it has violet lip of its apex. According to Comber

\footnotetext{
*Telp: 081310147064

Email: herbogor@indo.net.id
}

(1990), no hybridization occurs between big and small flower, even though, they were planted close together. Different pollinator might cause it. He said there is no available information to explain why those three groups split each other, therefore, it is interesting to study the variation among Arundina groups.

Structure of leaf anatomy so far was suitable to support in taxonomy studies. Several genera of orchid were successfully differentiated into species level by anatomical studies, such as Malaxis by examination and comparing of leaf anatomy (Davis 1997). Aerides by characteristic stomata types (Kaushik 1982), Subtribe Pleurothallidinae by trichomes, cuticle, epidermis and hypodermis (Pridgeon 1982), Caladenia by trichome, epidermis and mesophyll (Pridgeon 1993). In addition, Stern (1999), stated that character of leaf anatomy was also useable to explain relationship between Wullschlaegelia and Uleiorchis.

This paper presents the results of leaf anatomical study of three group of Arundina graminifolia, to clarify their taxonomic problem.

\section{MATERIALS AND METHODS}

Fresh materials were taken from Arundina graminifolia which planted in green house of Bogor Botanical Garden. Anatomical study carried out in 
Laboratory of Plant Morphology, Anatomy and Cytology, Herbarium Bogoriense, Bogor.

In order to perceive leaf epidermis, an impermanent paradermal slice, was prepared. Leaf cut of the size 1 $x 1.5-2 \mathrm{~cm}$, then put it into to nitric acid $65 \%$ :aquades (1:3); heated for about 10-15 minutes; and witted until its epidermis layer escape. It was washed in water, followed by colorant $1 \%$ safranin in aquades and mounted in glycerin $50 \%$. Anatomical analyses were examined under the light microscope Nikon AFX-IIA.

To get complete information on the leaf anatomy of $A$. graminifolia, such as anatomy of a vascular bundle, an existing cell under epidermis and epidermis position, preparation of transversal slide is needed. It followed Johansen (1940) with modification, material were fixed in FAA solution and dehydrated in 50\%-100\% alcohol and xylol. Infiltrated with paraffin. For coloration was used $1 \%$ safranin solution in $70 \%$ alcohol and fast green $2 \%$ in absolute alcohol.

\section{RESULTS AND DISCUSSION}

Description of morphology. Arundina graminifolia with big flowers and purple lip (group I). Terrestrial. Stems close together in a short rhizome, about $1-2 \mathrm{~m}$ high, sheath tubular, internodes $4-5 \mathrm{~cm}$ in above and $2.5-3 \mathrm{~cm}$ in the upper. Leaves lanceolate, grassy, dark green, 22-25 cm long, 1.6-1.7 cm wide, acute, coarsely. Terminal inflorescence, bearing many flowers, with one or two flowers open at a time. Flower spreading widely, sepals and petals free; median sepal ovate, $4.5 \mathrm{~cm}$ long, $1.4 \mathrm{~cm}$ wide, purplelish white; lateral sepals ovate, $4.5 \mathrm{~cm}$ long, $1.4 \mathrm{~cm}$ wide, purplelish white; petals ovate, $4.5 \mathrm{~cm}$ long, $2.5 \mathrm{~cm}$ wide, purplelish white; lib $5 \mathrm{~cm}$ long, $2.5 \mathrm{~cm}$ wide, violet, undulate.

Arundina graminifolia with small flowers and white lip (group II). Terrestrial. Stems close together in a short rhizome about $29-63 \mathrm{~cm}$ high, sheath tubular, and internodes $2-3.5 \mathrm{~cm}$ in above and upper. Leaves lanceolate, grassy, dark green to pale green, 14-17.5 $\mathrm{cm}$ long, $0.5-1 \mathrm{~cm}$ wide, acute, coarsely. Terminal inflorescence, , bearing many flowers, with one or two flowers open at a time. Flower spreading widely, sepals and petals free, median sepals lanceolate, $2.2-2.4 \mathrm{~cm}$ long, $0.2 \mathrm{~cm}$ wide, white; lateral sepals lanceolate, 2.3$2.5 \mathrm{~cm}$ long, $0.4 \mathrm{~cm}$ wide; petals ovate, $2.5-3 \mathrm{~cm}$ long, $0.8 \mathrm{~cm}$ wide, white; lip 2.7-3 cm long, $2.4-2.6 \mathrm{~cm}$ wide, white, yellowish at the base, margin undulate.

Arundina graminifolia with small flowers and purple lip at the apex (group III). Terrestrial. Stem $81.5-150 \mathrm{~cm}$, sheath tubular, internodes at base 4-5

Table 1. Leaf anatomy characters

\begin{tabular}{|c|c|c|c|}
\hline \multirow[b]{2}{*}{ Paradermal section } & \multicolumn{3}{|c|}{ Group of individuals } \\
\hline & Big flowers with purple lip & Small flowers with white lip & $\begin{array}{l}\text { Small flowers with purple lip at } \\
\text { the apex }\end{array}$ \\
\hline \multicolumn{4}{|l|}{ Stomata density } \\
\hline Mean & 10,898 & 8,809 & 9,81 \\
\hline $\begin{array}{c}\text { Range } \\
\text { Size of stomata }\end{array}$ & $6.52-14.28$ & $6.29-10.68$ & $8.60-12.13$ \\
\hline Mean $(\mu \mathrm{m})$ & $15.91 \times 11.18$ & $23.65 \times 18.705$ & $24.725 \times 17.415$ \\
\hline \multicolumn{4}{|l|}{$\begin{array}{l}\text { Size of lower epidermis } \\
\text { cell }\end{array}$} \\
\hline Mean $(\mu \mathrm{m})$ & $24.725 \times 17.16$ & $29.24 \times 16.125$ & $25.37 \times 14.19$ \\
\hline \multicolumn{4}{|l|}{$\begin{array}{l}\text { Size of upper epidermis } \\
\text { cell }\end{array}$} \\
\hline Mean $(\mu \mathrm{m})$ & $31.175 \times 16.125$ & $28.81 \times 20.20$ & $31.605 \times 17.2$ \\
\hline $\begin{array}{l}\text { Range }(\mu \mathrm{m}) \\
\text { Size of epidermis cell of } \\
\text { nerves }\end{array}$ & $15.05-43.0 \times 12.9-17.2$ & $19.35-45.15 \times 17.2-23.65$ & $17.2-45.15 \times 15.05-21.5$ \\
\hline Mean $(\mu \mathrm{m})$ & $33.54 \times 10.75$ & $31.805 \times 11.18$ & $29.82 \times 11.825$ \\
\hline Range $(\mu \mathrm{m})$ & $23.65-40.85 \times 8.6-15.05$ & $17.2-45.0 \times 8.6-12.9$ & $12.25-45.15 \times 10.75-15.05$ \\
\hline $\begin{array}{l}\text { Number of epidermis cell } \\
\text { of nerves }\end{array}$ & $5.0-16.0$ & $5.0-17.0$ & $6.0-12.0$ \\
\hline
\end{tabular}




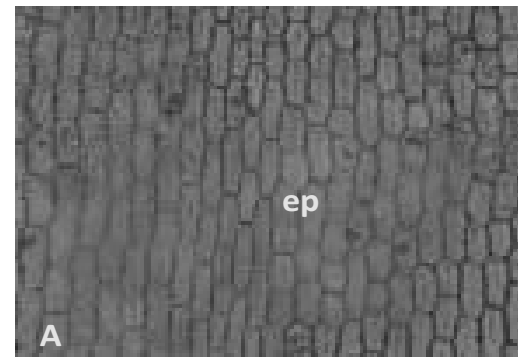

Figure 1. Upper epidermis of Arundina graminifolia big flower with purple lips (A), Arundina graminifolia small flowers with white lip (B), Arundina graminifolia small flowers with purple lip (C), ep: epidermal cell. Magnification 20x10.
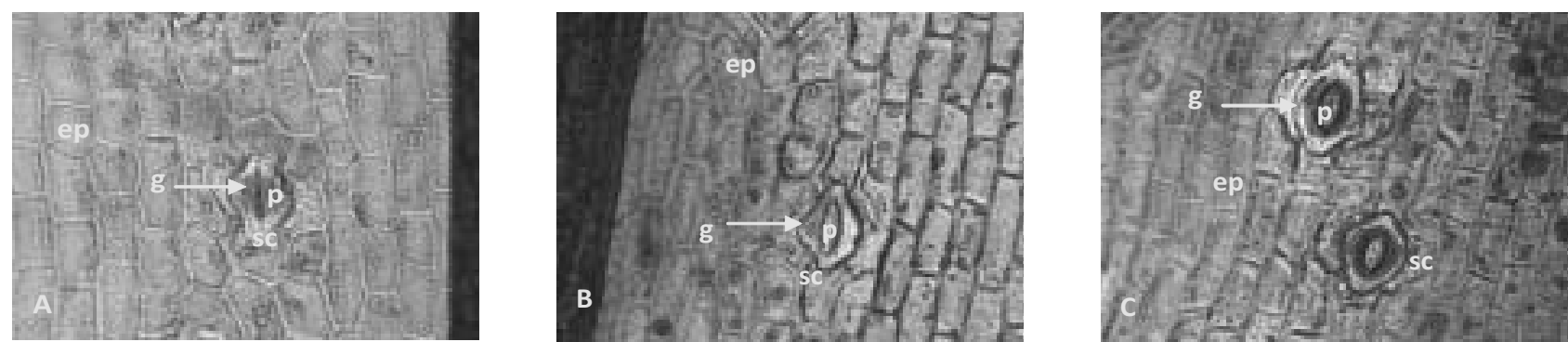

Figure 2. Lower epidermis of Arundina graminifolia big flower purple lip (A), Arundina graminifolia small flower with white lip (B), Arundina graminifolia small flower with purple lip (C), ep: epidermal cell, p: porus, g: guard cell, sc: subsidiary cell. Magnification 40x10.
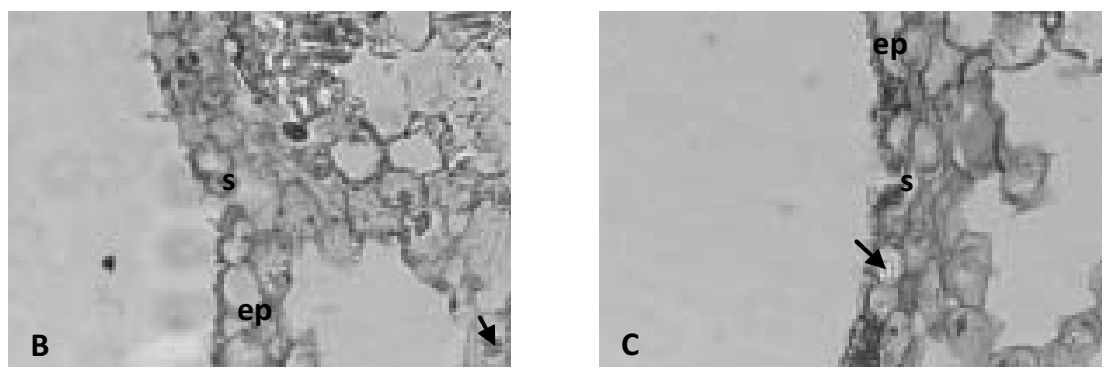

Figure 3. Leaf transverse section of Arundina graminifolia big flower with purple lip (A), Arundina graminifolia small flower with white lip (B), Arundina graminifolia small flower with purple lip (C), ep: epidermal cell , s: stomata, Ca-ocsalat crystaal (arrow). Magnification $40 \times 10$.
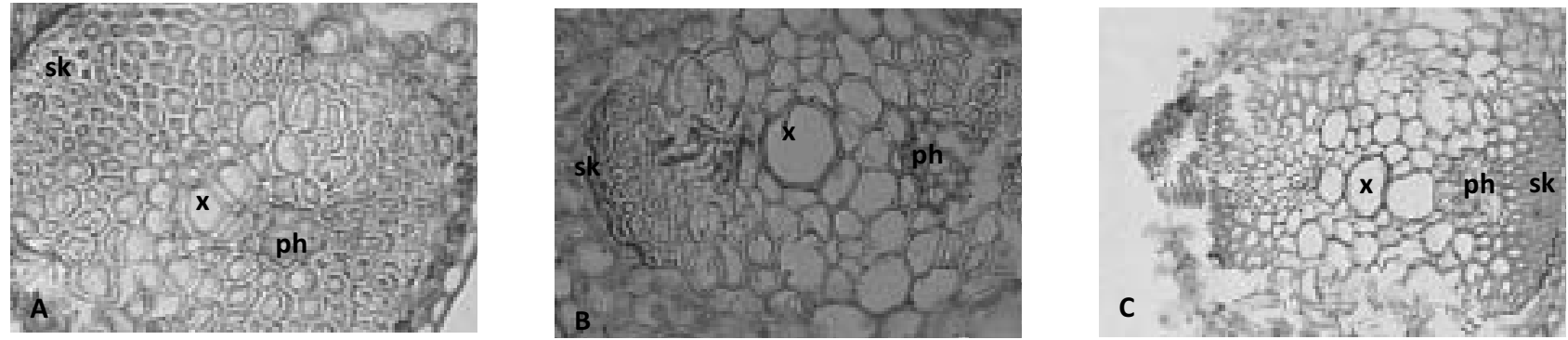

Figure 4. Midrib of Arundina graminifolia big flower with purple lip (A), Arundina graminifolia small flower with white lip (B), Arundina graminifolia small flower with purple lip individu (C), $x$ : xylem, ph: phloem tissue, sk: shlerenchyma tissue. Magnification $20 \times 10$. except (B) with Magnification $40 \times 10$.
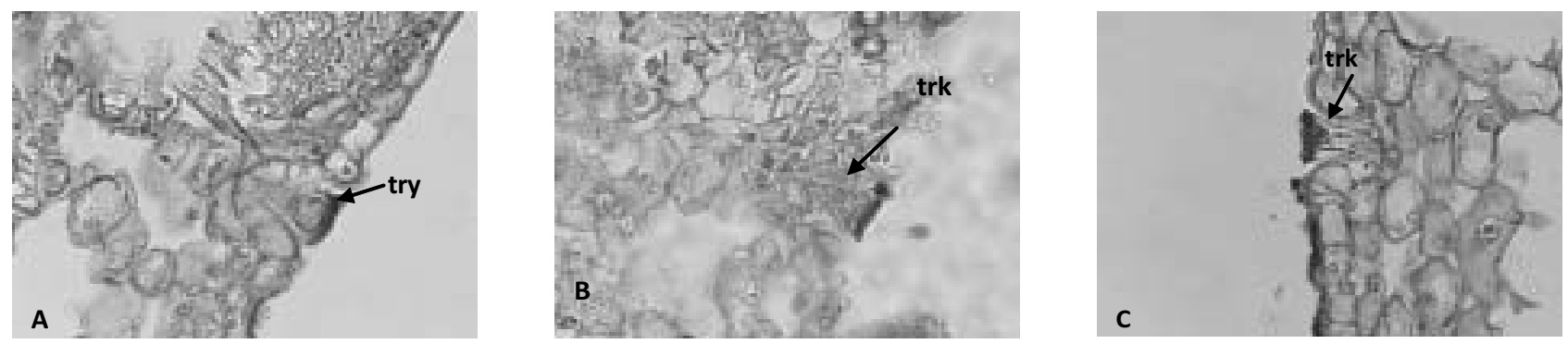

Figure 5. Trichome of Arundina graminifolia big flower wit purple lip (A), Arundina graminifolia small flower with white lip (B), Arundina graminifolia small flower with purle lip (C),trk: trichome. Magnification $40 \times 10$. 
$\mathrm{cm}, 1-3.5 \mathrm{~cm}$ at top. Leaves lanceolate, grassy, dark green to pale green, $8.5-2.5 \mathrm{~cm}$ long, $0.5-0.7 \mathrm{~cm}$ wide, acute, coarsely. Terminal inflorescence,, bearing many flowers, with one or two flowers open at a time. Flowers spreading widely, sepals and petals free; median sepal lanceolate, $2.5 \mathrm{~cm}$ long, $0.2 \mathrm{~cm}$ wide, white; lateral sepal lanceolate, $2 \mathrm{~cm}$ long, $0,3 \mathrm{~cm}$ wide, white; petals ovate, $2.5-3 \mathrm{~cm}$ long, $1 \mathrm{~cm}$ wide, white; lip $2 \mathrm{~cm}$ long, $2 \mathrm{~cm}$ wide, white, purple at the apex, margin undulate.

Leaf anatomy study. Paradermal section. In general, epidermis in form of trapezoid and polygonal, but for group of individual with white flower, purple lip there are some others epidermis structure, which is in form of elliptical. On the other hand, for group of individual with white flower, white lip there is some others epidermis structure in form of triangular and isodiametric (Figure 1). Size of epidermis among those three groups were overlapping, but base on average value (out of 10 measurements) for first and second groups tend longer, whereas for third group tend wider. The thickness of the upper epidermis wall are found in smaller white flower and purple lip groups with the thickness, whereas the thinnest one is in big flower group.

Stomata anomositic type only found in lower epidermis, positioned on parallel to epidermis surface (Figure 2).Therefore, base on average size of stomata the smallest stomata found in big flower group (Table 1).

The epidermis cell is smaller in big flower group, while the bigger is in small flower with white lip and small flowers with purple lip. However, the longest epidermis cell of nerves is found in big flowers whereas the shortest is found in small white flower and purple lip flower.

Transversal section. In transversal sections, show that all groups are covered with smooth and thin cuticle coat, and abaxial cuticle is thicker than adaxial cuticle. The position of stomata is parallel with epidermis surface (Figure 3). Glandular type trichome lays on both side of leaf surface with position is lower than epidermis surface. Top of trichome from the three groups are distincted.

Trichome of bigger flowers are club shape with its apex mucous, and for trichome of small white flower, white lip is also club shape with its apex mucous and granulate, while trichome for small white flower and purple lip looks like cup with wider fold in apex (Figure 5). Epidermis cell in form of elliptical and isodiametric are found for all groups, however, epidermis cell in form of square and polygonal is only found in small white flower with purple lip and small white flower with white lip respectively. Differentiated mesophyll is found in small white flower with white lip and in big flower but not in white flower with purple lip. The largest amount of mesophyll layers (10-13) is found in big flower and smallest amount is in small white flower with white lip (2), whereas in small white flower with purple lip is 9 11 layers. There are some crystal in form of druse, raphide and prism in all of groups, but different in their number and distribution. There is a lot of crystal and wider spread in small white flower with white lip but not in the two other groups (Figure 4).

According to Stuessy (1990), a plant categorized at variety level when it has one or two differences in morphology character, allopathric distribution pattern, and unable to hybrid each other or reduces in fertility although they are overlapping distribution. These differences are obtained among groups of Arundina graminifolia, although they were planted in one area but unable to hybrid each other. Based on this fact, the taxonomic status of group individuals with white small flower, with white and purple lip might be dissociated from big flower group.

\section{Key to the group based on leaf anatomy.}

1 a. Mesophyll consists of 9-13 layers, no differentiation (2).

b. Mesophyll consists of 2 layers, differentiated (Arundina graminifolia group II).

2 a. Trichome club shape (Arundina graminifolia group I).

b. Trichome cup shape (Arundina graminifolia group III).

\section{CONCLUSSIONS}

Results of anatomical study showed that trichome is the major character in order to differentiate among group of Arundina graminifolia, while the number of mesophyll layer is the minor character. Based on the differences in size of flower and their color variation, and combines with results of leaf anatomical study, we recommend that three groups of Arundina graminifolia are classified as separate groups. 


\section{ACKNOWLEDGEMENT}

We would like to thanks to Plant Morphology, Anatomy and Cytology Laboratory, Botany Division (Herbarium Bogoriense), Research Center for Biology, Indonesian Institute of Sciences.

\section{REFFERENCES}

Comber, J.B. 1990. Orchids of Java. Bentham-Moxon Trust. Kew: Royal Botanic Gardens.

Davies, K. L. 1999. A Preliminary survey of foliar anatomy in Maxillaria. Lindleyana 14: 126-135.
Johansen, D. A. 1940. Plant Microtechnique. $1^{\text {st }}$ Edition. New York: Mc Graw Hill Book Company, Inc.

Kaushik, P. 1982. Anatomy of Aerides (Orchidaceae) and its ecological and taxonomical bearing. Phytomorphology. An International Journal of Plant Morphology 32(2,3): 157-166.

Pridgeon, A. M. 1982. Diagnostic Anatomical Characters in The Pleurothallidinae (Orchidaceae). American Journal of Botany 69: 921-938.

Pridgeon, A. M. 1993. Systematic leaf anatomy of Caladenia (Orchidaceae). Kew Bulletin 48: 533-543.

Stern, W. L. 1999. Comparative vegetative anatomy of Two Saprophytic Orchids from tropical America: Wullschlaegelia and Uleiorchis. Lindleyana 14: 136-146.

Stuessy, T. F. 1990. Plant Taxonomy. The Systematic Evaluation of Comparative Data. New York: Columbia University Press. 